\title{
ARIS
}

UK \& Ireland

Art Libraries Society

\section{'Creative Partnerships'}

\section{ARLIS/UK \& Ireland Annual Conference 2003 University of Sussex at Brighton Thursday 3rd - Sunday 6th July 2003}

Our conference this year is located in the heart of the South Downs in a Designated Area of Outstanding Natural Beauty. Sympathetically landscaped, the University of Sussex campus has distinctive and stylish buildings, many of them (including the Library) designed by the celebrated architect Sir Basil Spence. Easily accessible from the University is the cosmopolitan town of Brighton. Often dubbed 'London by the sea' because of its vibrant atmosphere, the town also boasts some of the finest examples of Regency architecture in England.

Our conference theme touches on some of the most important issues currently facing art and design librarians: cross-sectoral and cross-agency working; collaboration and partnership with our users, our suppliers, our colleagues in other professions.

Programme highlights include:

$>$ Tim Padfield, Curator of Photographs at the Public Record Office, on Copyright and the use of images

$>$ Val Buchanan and Julia Gaimster, London College of Fashion, on the development of virtual learning environments

$>$ Margaret Graham, Director of Research at the Institute for Image Data Research, on the work of IIDR

$>$ Plus workshops, study visits, the opportunity to network with colleagues.

For more information on the Conference Programme in the coming months check out the ARLIS/UK \& Ireland website:

$\underline{\text { http://arlis.org.uk/ }}$

or contact

Sonia French, Administrator, ARLIS/UK \& Ireland, 18 College Road, Bromsgrove, B60

2NE, England

Tel: $+44(0) 1527579298$

Email: sfrench@arlis.demon.co.uk 


\section{Design and Applied Arts Index (DAAI) \\ 10,000-12,000 RECORDS / YEAR • UPDATED 9 TIMES A YEAR • BACKFILES TO 1973 130,000 TOTAL RECORDS}

\section{Now published by CSA}

Design and Applied Arts

Index (daai) is the main

bibliographic source for

current material and

information in the areas of design and the applied arts worldwide. As the market leader, it is an indispensable resource for researchers, students, and librarians in the field, as well as for active designers and artists.

daai covers more than 500 international design and craft journals

published since 1973, and contains data on almost 55,000 designers, craftspeople, studios, workshops, firms, etc.

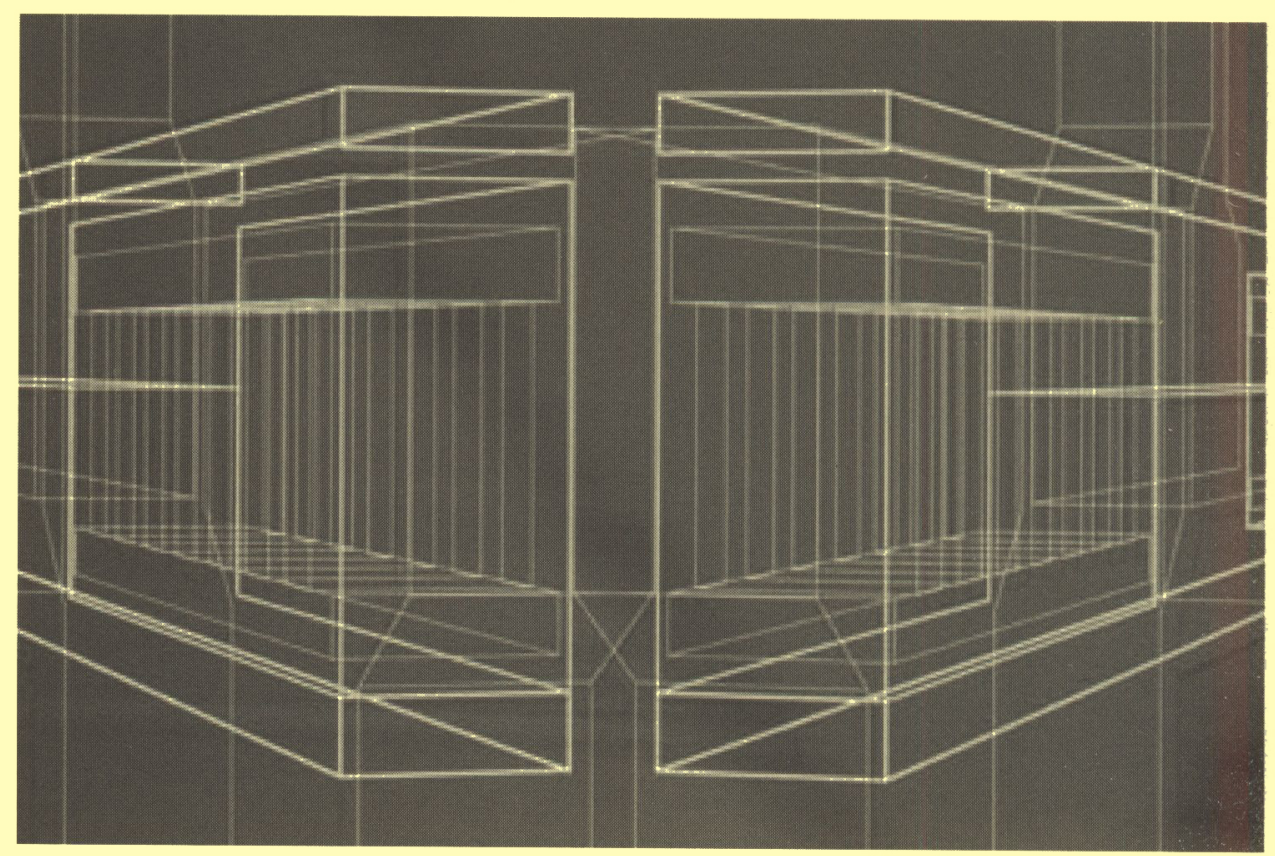

Subject coverage includes:

- Advertising

- Architecture

- Book design

- Calligraphy

- Ceramics

- Computer graphics

- Crafts

- Design for disability

- Design history

- Design theory
- Education

- Environmental design · Jewellery

- Exhibition design

- Fashion

- Fibre arts

- Furniture

- Glass

- Graphic design

- Illustration

- Industrial design
- Interior design

- Metalwork

- Packaging

- Photography

- Structural design

- Textiles

- Theatre design

- Typography

- Vehicle design

\section{Currently available on CD-ROM or on the Web!}

Forthcoming on the Internet Database Service from CSA. 